\title{
The Ability of Writing Cerpen Procuredly Through Experiential Learning Students of Class IX Junior High School
}

\author{
Musyawir ${ }^{1}$, Hamzah $^{2}$ \\ ${ }^{1,2}$ Indonesian Language Program, FKIP Iqra Buru University (UNIQBU), Indonesia \\ ․ㅡusyawir.rs@gmail.com, ${ }^{2}$ hamzah123@gmail.com
}

\section{Keywords:}

Writing,

Short Stories,

Daily Observations of

Events

\section{ABSTRACT}

This study aims to determine the ability of students of class IX SMP Buru 11 in writing short stories in stages through observation of the daily events of experiential learning. This research is a quantitative descriptive study. Namely by describing the profile of student learning outcomes by utilizing ways of interpretation by presenting in the form of descriptions. The results of this study indicate that (1) The ability to write short stories in stages through observation of daily events Experiential Learning in SMP Negeri 11 Buru has been successful, but not yet optimal, (2) aspects of the accuracy of diction which do not meet the maximum value, from the total sample of 26 students who scored 65 and above was 16 people (62\%) and 10 students who scored below 65 (38\%). This means that the ability of grade IX students of SMP Negeri 11 Buru in writing short stories in stages through observation of daily events (Experiential Learning) is categorized as sufficient..

\section{A. INTRODUCTION}

Literature is a form and result of creative art work whose objects are human beings and their lives by using language as the medium. As a creative work, literature must be able to give birth to a beautiful creation and try to channel the needs of human beauty, Semi (Semi, 1988). Literary work is one of the results of art. There is another that refers to as a work of fiction. The role and presence of characters in a fiction literary work is very important in conveying messages, criticism and ideas to the reader. Fiction literary works present figures with diverse characteristics and characteristics.

Fiction is often also called a fictional story is a story in prose, is the result of the author's processed based on his views, interpretations, and judgments about events that have occurred or the processing of events that only took place in Semi (Semi, 1988). The same was conveyed by Stanton, quoted by Kosasih (Kosasih, 2012) who explained that fiction is life, while life is the most interesting game. Reading good fiction is like playing a game with a high degree of difficulty and not like playing a trivial game where the players simplify or even ignore the rules. 
That is, when we read a fiction requires a high interpretation to be able to capture what the author wants to convey in the story.

Luxemburg, et al who in Purba (Purba, 2012) put forward five literary characteristics as follows, namely 1 . Literature is a creation, a creation, not merely an imitation. Literature is primarily a spontaneous overflow of emotions. 2. Literature is autonomous, does not refer to another one. Literature is not communicative. The poet only seeks harmony in his own work. 3 . Autonomous literary works are characterized by coherence. 4. Literature conveys an antithesis between contradictory matters. 5 . Literature reveals what is not revealed by poetry and other forms of literature caused by various kinds of associations and connotations.

The learning process of writing short stories should take place in contextual learning (Winahyuningsih, 2019). That is, the learning process takes place by linking the subject matter with the real life of students. The application of the appropriateness of the subject matter with the level of emotional, intellectual and psychological development of students becomes an important consideration.

Based on this opinion it can be concluded that literary learning is the process of delivering knowledge by teachers to learners towards a broad system that moves which consists of components that lead to the growth of learners towards an expected goal through the process of enjoying, understanding, and appreciating the results of creativity human. One of the media is through literary works which are expected to be appreciated by learners.

The 2006 curriculum, stated that Indonesian language learning is directed to improve the ability of students to communicate in Indonesian properly and correctly, both verbally and in writing, as well as foster an appreciation of the results of Indonesian literary works. The scope of Indonesian language subjects in the SBC includes the components of language skills and literary abilities which include aspects of listening, speaking, reading, and writing (Sugiantomas et al., 2017).

Literature is a work that is the result of imagination, creativity, and expression of its creator which contains aesthetic values, because literature is compiled using beautiful and unique languages so that readers can indirectly learn, feel, and appreciate the various problems of life that deliberately offered by the author. Because, in literature contains the value to be conveyed by its creator. This is in line with the opinion of Wellek and Werren cited by Nurgiyantoro saying that the purpose of providing entertainment, pleasing and satisfying readers is essential in literature. In addition, Abrams, quoted by Nurgiyantoro (Nurgiyantoro \& Efendi, 2013), revealed that literature is able to stimulate the imagination of children, able to provide pleasure as well as provide a better understanding of this life.

Learning writing skills is one of the language skills that is no less important and must be mastered by students with other language skills. In KTSP it has been mentioned that from the perspective of language skills, writing is an active and productive activity (Nurjanah, 2006). Writing skills in teaching literature are skills that are not easy. This skill requires a person's ability to express ideas, ideas, thoughts, and feelings to become a work so that other people can understand the work. Writing can be said to be easy if you do it often and it is difficult if you are not familiar. Because, as a skill, to obtain it must be through learning and practicing.

One of the problems facing our education world is the problem of the weak learning process. In the learning process, children are less encouraged to develop thinking skills. The learning process in the classroom is directed at the child's ability to memorize information without being required to understand the information that is remembered to connect it with everyday life. Weak learning process in class almost happens in all subjects, Indonesian subjects are no 
exception. Education in schools is too much stuffed with children's brains with a variety of teaching materials that our education must be memorized not directed to form intelligent people, have the ability to solve life problems, and are not directed to form creative and innovative human beings, Sanjaya (Sanjaya, 2010). Writing skills are one of the language skills that must be taught to students.

Writing skills have a very important role in daily life. Writing short stories in stages through daily observations IX-3 SMP Negeri 11 Buru is a new thing that students do in the process of writing short stories. Every student in daily life must have observations that he has gone through. From these observations, of course students have experiences that they have passed. From those observations and experiences students can pour in a short story writing.

Based on this background, the researcher will conduct research with the title of the ability to write short stories in stages through observation of daily events (experiential learning) grade IX3 students of SMP Negeri 11 Buru, Namlea District.

Furthermore, the formulation of the problem in this study is how the ability of class IX-3 students of SMP Negeri. The purpose of this study was to determine the ability of students of class IX-3 SMP Negeri 11 Buru in writing short stories in stages through observing daily events (Experinecial learning). The benefits of this research are contributing theoretical thinking in the form of innovative short story learning teaching and learning process by tiering through observation of daily events (experiential learning), to students, namely gaining new experiences and helping students in writing short stories, and to the teacher, results this research is expected to be able to provide input to Indonesian language study teachers in writing short stories in stages through observation of daily events (experiential learning).

\section{B. METHODS}

This type of research uses quantitative descriptive research. Namely by describing the profile of student learning outcomes by utilizing ways of interpretation by presenting in the form of descriptions (Arikunto, 2010). The data generated from this study are data in the form of a short story writing ability test in stages through observation of daily events (experiential learning) grade IX-3 students of SMP Negeri 11 Buru, Namlea District, Buru District.

Data collection techniques used in this study were observation techniques, tests, and interviews (Sugiyono, 2013). These three techniques are selected based on the required data criteria. In addition, the technique is considered appropriate for use in data collection with a learning background.

Observation technique is carried out by directly observing the implementation of the action learning of short story writing skills in stages through observation of daily events (experiential learning). Observations are made with the guidelines on the observation sheet that has been prepared. Observation activities are directed to obtain data about the activities carried out by students and teachers at each stage of learning the short story writing skills.

Interviews were conducted through question and answer with students to find out their understanding and opinions on activities in the process and learning outcomes of short story writing skills. Besides students, interviews were also conducted with collaborator teachers. Both interview results are used to strengthen observational data that occur in class.

Data collection techniques with the test carried out by assigning students to write short stories in stages through observation of daily events (experiential learning). The test is carried 
out every action in one cycle and analyzed. This result is used to measure student mastery individually and classically.

Next, the data collected was analyzed in a quantitative description. Process data were analyzed in a qualitative description. Process data that has been collected is analyzed with the following steps: Data Analysis, Data Reduction, Present Data.

\section{RESULT AND DISCUSSION}

The results showed that the ability of students, grade IX-3 students of SMP Negeri 11 Buru to write short stories in stages through observation of daily events (Experiential Learning) was categorized as inadequate. This is stated because the acquisition of student grades has been completed in KKM. However, not yet maximized. The low score certainly affects the ability of students collectively.

Based on the sample of students who were given tests as many as 26 samples about writing short stories in stages through observation of daily events (Experiential Learning), of the 5 indicators used as aspects of the assessment aspects of portrayal of inadequate characters in achieving completeness grades of 26 students used as samples scored 65 and above as many as 16 people (62\%) and 10 students who scored below 65 (38\%). This means that the ability of grade IX-3 students of SMP Negeri 11 Buru to write short stories in stages through observation of daily events (Experiential Learning) is categorized as inadequate. This is stated from the 5 indicators used as aspects of assessment in writing short stories depicting aspects of characters who get inadequate values.

Based on the description it appears that the ability of students to write short stories in stages through observing daily events (Experiential Learning) is categorized as not yet. This is one indicator that learning to write short stories in stages through observation of daily events (Experiential Learning) in SMP Negeri 11 Buru has succeeded, but not yet maximized.

The level of mastery of writing short stories in stages through observation of daily events (Experiential Learning) of Namlea 11 Public Middle School is still relatively not maximal overall. Therefore, the results of this study are an input for Indonesian language teachers in junior high schools, especially Namlea 11 Public Middle Schools. Thus, it should be taken seriously in writing short stories.

\section{CONCLUSION AND SUGGESTIONS}

Based on the results of data analysis and discussion, it can be concluded that the ability to write short stories in stages through observation of daily events (Experiential Learning) at SMP Negeri 11 Buru has been successful, but it has not been maximized. This can be seen in the indicators used as aspects of the assessment in writing short stories in the aspect of diction accuracy that have not met the maximum value, from the sample of 26 students who scored 65 and above as many as 18 people (69\%) and 8 students who scored below 65 (31\%). This means that the ability of grade IX-3 students at SMP Negeri 11 Buru to write short stories in stages through observation of daily events (Experiential Learning) is categorized as inadequate. This was stated because of the 26 students who were given the test, as many as 18 students (69\%) were able to get a score of 65 and above. Did not reach the criteria of the ability of the sample students, which was $85 \%$. Based on these conclusions, the following suggestions are made. The learning of Indonesian language and literature in class IX-3 students of SMP Negeri 11 Buru should be further improved by always providing training to students in writing short stories. 


\section{6 | IJECA (International Journal of Education and Curriculum Application)}

Vol. 1, No. 2, August 2018, pp. 72-76

Students should be more active in practicing short story writing using various methods and approaches so that the ability to write short stories can be further improved.

\section{REFERENCES}

Arikunto. (2010). Suharsimi Arikunto.pdf. In Prosedur Penelitian Suatu Pendekatan Praktik-Revisi ke X.

Kosasih. (2012). Dasar-Dasar Keterampilan Bersastra. Bandung, Yrama Widya.

Nurgiyantoro, B., \& Efendi, A. (2013). Prioritas Penentuan Nilai Pendidikan Karakter Dalam Pembelajaran Sastra Remaja. Jurnal Cakrawala Pendidikan, 3(3). https://doi.org/10.21831/cp.v3i3.1626

Nurjanah, E. (2006). Pengembangan E-Bookinteraktif Pada Materi Menyimak Unsur-Unsur Intrinsik Cerpen Berbasis Kearifan Lokal Pangkalan Bun Pada Siswa Kelas Xi Sma Negeri 1 Kumai. Jurnal Pendidikan Bahasa Indonesia, 3, 388-397.

Purba, A. (2012). Sastra Indonesia Kontemporer. Sastra Indonesia, 50.

Sanjaya, W. (2010). Strategi Pembelajaran Berorientasi Standar Proses Pendidikan. In System (Vol. 6, Issue 1, pp. 140-151).

Semi, M. A. (1988). Anatomi Sastra. In M. Atar Semi, Anatomi Sastra, (Padang: Angkasa Raya, 1988), Cet. Ke1, h. 36.

Sugiantomas, A., Jaelani, A. J., \& Aeniroh, O. N. (2017). Perbandingan SK dan KD Pada Standar Isi Kurikulum 2006 Dengan KI dan KD Pada Standar Isi Kurikulum 2013 Mata Pelajaran Bahasa Indonesia Sma Kelas XII Dilihat Dari Taksonomi Tujuan Pembelajaran, Cakupan Keterampilan Berbahasa, Ilmu Kebahasaan, Dan Ilmu Kesastraan. FON : Jurnal Pendidikan Bahasa Dan Sastra Indonesia, 10(1). https://doi.org/10.25134/fjpbsi.v10i1.1028

Sugiyono. (2013). Buku - Sugiyono. In Metode Penelitian Kuantitatif, Kualitatif, dan R \& D (p. 407).

Winahyuningsih, C. E. (2019). Peningkatan Kemampuan Menulis Cerpen Berdasarkan Pengalaman Pribadi Dengan Metode Resitasi Pada Siswa Kelas XI KRB SMK Negeri 1 Rembang Tahun Ajaran 2017/2018. Sasindo, 6(1). https://doi.org/10.26877/sasindo.v6i1.3704 